\title{
BUDGETARY TRANSFER AS A TOOL FOR FINANCING THE HEALTH SECTOR: THEORETICAL LEGAL ANALYSIS
}

DOI: 10.36740/WLek202012225

\author{
Oleksandr A. Lukashev ${ }^{1}$, Ihor Y. Krynytskyi' ${ }^{2}$, Serhii V. Broiakov' ${ }^{1}$ \\ ${ }^{1} Y$ YROSLAV MUDRYI NATIONAL LAW UNIVERSITY, KHARKIV, UKRAINE \\ ${ }^{2}$ LAW DEPARTMENT OF POLTAVA LAW INSTITUTE OF YAROSLAV MUDRYI NATIONAL LAW UNIVERSITY, POLTAVA, UKRAINE
}

\begin{abstract}
The aim: The purpose of the study is to: a) determine the purpose of budget transfers in the field of medicine; $b$ ) determine the characteristics that characterize budget transfers in the health sector; $c$ ) establish the significance of budget transfers in those jurisdictions in which the system of health insurance operates.

Materials and methods: The empirical basis of the study was the Report of the Minister of Health of Singapore, Information on the subvention section for $2019-2020$ in Hong Kong, the Budget forecast of the US Congress for 2019, Reports of the Accounts Chamber of Ukraine for 2017, 2018 and 2019. Within the framework of this study, the following special legal methods of scientific knowledge were applied: comparative legal method, a normative-dogmatic method and a logical-legal method. The "case study" method was also widely used in this research.

Conclusions: Budget transfers in the field of medicine is a socially important institution of budget law. Budget transfers in the health care sector can be characterized by the following features: a) sectoral nature (health care sector) b) specific budgetary directions (movement of funds from the state to local budgets) c) widespread use (used both in states with medical insurance and in states where the health sector is entirely publicly funded).
\end{abstract}

KEY WORDS: budget transfers, subventions, medical subventions, financing of medicine, the health sector

Wiad Lek. 2020;73(12 p. II):2855-2859

\section{INTRODUCTION}

Public finance plays an important role in ensuring the proper functioning of the health sector. Financing of medicine is one of the most socially important budget expenditures. There is an objective need to form a flexible mechanism for financing health care. One of the main instruments for establishing the appropriate flexibility is the institution of budget transfers. In countries that are focused on decentralization processes, budget transfers are a kind of instrument for "supporting" local budgets. Moreover, budget transfers are applied in all states, regardless of the administrative-territorial structure and form of government.

\section{THE AIM}

The practice of using budget transfers to ensure financing of the health sector is widely developed. At the same time, the variability of approaches to the formalization of this institution was stated. The objective of this study is to study the main aspects of the budget transfers regulation in the health sector.

\section{MATERIALS AND METHODS}

The empirical basis of the study was the Report of the Minister of Health of Singapore, Information on the subvention section for 2019-2020 in Hong Kong, the Budget forecast of the US Congress for 2019, Reports of the Accounts Chamber of Ukraine for 2017, 2018 and 2019. Within the framework of this study, the following special legal methods of scientific knowledge were applied: comparative legal method, a normative-dogmatic method and a logical-legal method. The "case study" method was also widely used in this research.

\section{REVIEW AND DISCUSSION}

Budget transfers in the health sector are widely used in various states. The main primary sources for the study of budget transfers should be the reports of the authorized bodies (long-term plans, forecasts), which analyze the procedure for using transfers to finance medicine. From the subvention distribution program for 2019-2020, it follows that the bulk of subventions in Hong Kong is directed precisely to the healthcare sector $(36,6 \%$ of the total number of subventions) [1]. At the same time, individual states, in particular, the United States, pay attention to the growth of medical expenses due to the increase in the beneficiaries of medical care. This is due, among other things, to the growing aging of the nation [2, p. 3]. From the analysis of the Report of the Minister of Health of Singapore, it follows that spending on the health sector in 2019 compared to 2018 increased, which necessitated an increase in subventions for medicine [3, p. 123]. 
This study also analyzed empirical materials related to budget transfers in Ukraine. We've found inconsistent approaches to the study of budgetary transfers to health care in the reports of the Accounting Chamber of Ukraine. The establishment of such an inconsistency of the Ukrainian supervisory authority raises questions. This necessitated the study of foreign approaches to the application of the institution of budget transfers in the health sector.

D. Clark notes that the task of proper regulation of public financing of medicine is: a) to minimize the inefficiency of the use of budget funds; b) to develop mechanisms for filling budgets; c) to develop efficiently functioning financial institutions; d) to ensure transparency and accountability of health financing mechanisms [4, p. 14].

Firstly, we should define such a concept as "budget transfers". Budget transfers are public funds that are transferred from one budget (federal budget, budget of a constituent entity of the federation, state budget, local budget) in favor of another budget. Accordingly, the following types of budgets can be conditionally distinguished: a) the "donor budget" (budget from which public funds are allocated) b) the "recipient budget" (budget in favor of which funds are allocated). Budgetary transfers are intended to provide efficient and flexible management of budget funds. Budget transfers can be classified according to several criteria. Depending on the purpose of the funds allocated, budget transfers can be divided into a) targeted (aimed to provide funding for a specific sphere of public life); b) aimless (allocated without indicating of their use; allows the managers of funds to independently choose the directions of their use). According to the specifics of the "direction" of funds movement, they are divided into: a) "vertical" budget transfers (funds are allocated from the budgets of the higher level in favor of the budgets of the lower level (in the case of a federal structure) from state budgets in favor of local budgets (in unitary states)) b) "horizontal" budget transfers (the movement of funds occurs between budgets of the same level). Budgetary transfers to health care are mainly targeted, "vertical" transfers. This is due to the understanding of the industry for which such funds are directed and the support of the central authorities to the local level of medical sector.

Targeted budget transfers in health financing are widely used. The following countries use such transfers: Japan, Singapore, Switzerland, Netherlands, Taiwan, USA [5], China (PRC) [6], Colombia [7, p. 41], Bulgaria [8, p. 142], Canada [9], Poland, Hungary, Czech Republic, Slovakia, Slovenia, Croatia, Estonia [10], etc.

The use of funds allocated for the medical sector in budgetary transfers depends on the model of medicine that is used by a particular country - it differs in states with medical insurance and states without medicine insurance; is excellent in economically developed countries and developing ones.

The problems associated with the use of budget transfers in the health care sector in China were studied by Liu K., Yang J. Lu S. In China, where elements of insurance medicine have been introduced, namely social and medical insurance, in order to ensure financing of medical services for the population with low-income subventions are used as part of medical and financial support programs. The aforementioned researchers note that, in fact, such budget transfers perform two tasks at once: 1) finance the participation of the poor population in China in social and health insurance; 2) ensure the purchase of medicines for such segments of the population. With the help of the program of medical and social support, 50.1\% of low-income families participated in social health insurance programs, and $24.1 \%$ of such families received funds to purchase medicines [6]. In China budgetary funds in budget transfers are allocated not to ensure financing of medicine in full, but only to create conditions for participation in general health insurance programs for low-income segments of the population. In addition, funds from such programs are used to cover the costs of the drugs that such category of the population need. Colombia took a similar approach for reforming healthcare financing mechanisms in the 1990s. As D. McIntyre noted, in Colombia transfers from the state budget could only be used to ensure the participation of low-income segments of the population in medical and social insurance programs. At the same time, in the transition period, there was no complete cessation of budgetary support for hospitals [7, p. 41].

Another interesting example is the countries of Eastern Europe (Poland, Hungary, Czech Republic, Slovakia, Slovenia, Croatia, Estonia), which in 1990s carried out a reform of the national medicine financing system. The experience of the aforementioned countries has been studied by such scientists as I. Wilki and I. Mathauer. These scientists note that the countries of Eastern Europe were previously included in the sphere of political influence of the Union of Soviet Socialist Republics (USSR), which certainly could not but affect the system of financing national health systems. In the 1990s, the countries of Eastern Europe began the transition to insurance medicine, which, however, was not possible without state financial support for this area during the transition period. Moreover, even today social and medical insurance for certain vulnerable groups of the population is completely free (funded by transfers from the budget). Budget transfers were introduced simultaneously with the beginning of the reform of the healthcare financing system (except for Estonia, which started introducing social health insurance in 1992 and introduced budget transfers only in 1999). These vulnerable groups of the population mainly include: a) unemployed; b) pensioners; c) persons receiving social assistance; d) poor; d) persons under the age of 18 . At the same time, in some countries (Czech Republic, Hungary, Estonia, Croatia), the number of persons whose participation in social and medical insurance is financed by budgetary transfers includes military personnel (not socially vulnerable groups) [10]. Thus, we must summarize that the financing of social and medical insurance for vulnerable groups of the population is not just an instrument of the transition period, but a completely effective mechanism for the implementation of social tasks. 
Further, it is necessary to analyze the movement of such budgetary funds depending on the policy of administrative-territorial management applied by the state.

"Vertical" budget transfers are important not only for countries that have started the decentralization process, but also for countries with a traditionally strong municipal organization. For example, we can cite the United States, whose experience was studied by D. Vildasin. The scientist notes that in the United States transfers from the federal budget in favor of local budgets is a sustainable mechanism for ensuring the financial stability of such local budgets. At the same time, the healthcare sector is one of the areas that receive additional funding because of budget transfers [11 p. 47-48]. This indicates that the use of budget transfers (including subventions) as mechanisms for additional capitalization of health care is widely used not only in developing countries, but also in developed countries. Budgetary transfers for finance the health care sector are important to developing countries. Rajan D., Barrow H. and Stenberg K studied the experience of Mexico in this area. Researchers note that about $85 \%$ of all funds that are included in the federal budget for financing medicine is allocated from the federal budget of Mexico in favor of state budgets [12, p. 14]. This indicates a significant level of decentralization of management processes in Mexico in the budgetary sphere.

In Canada, budgetary transfers to health care sector have undergone a significant transformation. The Department of Finance of Canada studied historical stages of budget transfer institution for healthcare. This type of budgetary transfers received a relatively clear sectoral institutionalization in 1995 in the form of the Canadian medical and social transfer. In 2004, this unified transfer was subdivided into separate transfers - the Canadian Medical Transfer and the Canadian Social Transfer. These budget transfers are channeled from the federal budget to the budgets of the provinces and territories. These budget transfers are increasing every year (demonstrates positive financial dynamics). At the same, time in terms of accountability the main emphasis was shifted to state control over the targeted use of such funds to public control of the use of these funds at the provincial and territorial levels [9]. The Canadian experience demonstrates the need for a constant options search for the optimal institutionalization of budget transfers through which the financing of the health sector occurs. The modernization of budget transfer institutions should not be viewed as a negative factor, as the example of Canada demonstrates.

In Ukraine, the experience of public medical guarantees also exists. The National Health Service of Ukraine provides the implementation of such guarantees. Similar bodies exist in other countries: Public Health Agency in Sweden (Folkhälsomyndigheten); Federal Office of Public Health in Switzerland (Bundesamt für Gesundheit); National Public Health Organization in Greece (E0vıкós

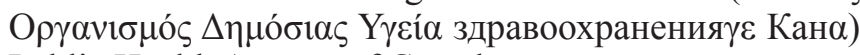
Public Health Agency of Canada etc.

The experience of Ukraine in the application of the budget transfers institution is also interesting. The model of budget transfers using for the purpose of financing medicine in Ukraine demonstrates an emphasized "paternalistic" approach. The Ukrainian approach contrasts significantly with the approaches of the states in which insurance medicine is established. In Ukraine today the transition to insurance medicine is only being declared. The Concept for the reform of the health care system financing (approved by the order of the Cabinet of Ministers of Ukraine from 30.11.2016 No. 1013-r) determines the need to establish an insurance medicine system [13]. First of all, it should be noted that in Ukraine there is a mechanism of full state financing of medicine, whose ineffectiveness has been repeatedly confirmed. This undoubtedly testifies the need to reform. As a "transitional elements" for the transformation of this system we could name medical subventions. Medical subvention is one of the elements of ensuring decentralization in Ukraine. However, in the future with the introduction of insurance medicine in Ukraine medical subventions can be modernized.

Medical subventions were introduced with the adoption of the Law of Ukraine "On Amendments to the Budget Code of Ukraine on the Reform of Budgetary Relations" from 28.12.2014 No. 79-VIII. This type of subvention is relatively new. First, we should define the content of such a general concept for the theory of financial law as "subvention". The term "subvention" comes from the Latin word "subvenio", which means "come to rescue" [14, p. 467]. The legislative definition of this concept has been formalized in the Budget Code of Ukraine. Subvention is a budgetary transfer for a specific purpose the use of which is determined by the body that made the decision to provide such subvention [15]. The defining characteristic of the subvention is its target nature - the subvention is assigned and used for a specific purpose.

A medical subvention is a transfer that is provided from the State Budget of Ukraine to local budgets. The importance of medical subventions is confirmed by the provisions of Appendix No. 6 "Budget transfers (educational and medical subventions, base and reverse subsidies) for 2019" to the Law of Ukraine "State Budget of Ukraine for 2019" from 23.11.2018, where the medical subvention in fact, it is the second most important budget transfer, second only to educational subvention - the size of medical subvention for 2019 is 55 billion of UAH (in EUR equivalent 1,6 billion) [16]. Despite the pandemic of coronavirus infection COVID-19 in 2020, the total amount of medical subvention is even less - 14, 5 billion of UAH (in EUR equivalent 433 million) [17]. Despite the issue of the effectiveness of the use of medical subventions, it has repeatedly become the subject of research by the Accounts Chamber of Ukraine (Reports of Accounts Chamber for 2017, 2018 and 2019). The reports for 2017 and 2018 indicate the inconsistency of the supervisory authority in their preparation (in terms of medical subvention). The situation moved in a positive direction in 2019. So, in the report of the Accounts Chamber on 2019 much more attention was paid to the issues of medical subvention. In particular, direct violations or shortcomings in the use of 
the amounts of such medical subventions in the amount of 4.3 billion was found. UAH [20].

The Budget Code of Ukraine determines the legal mechanism of medical subvention. The medical subvention is used for special items of local budgets - expenditures related to the health care sector. Normative regulation of medical subventions is characterized by dualism - regulation takes place both at the level of law (the Budget Code of Ukraine [15]) and at the subordinate level (resolutions of the Cabinet of Ministers of Ukraine) [21;22]).

Medical subventions are one of the instruments that provide public funding for the health sector. At the same time, after the transition to insurance medicine medical subventions can be reformatted into a tool for ensuring participation in the health insurance programs of persons that belong to unprotected segments of the population.

\section{CONCLUSIONS}

Budget transfers in the field of medicine is a socially important institution of budget law. Budget transfers in the health care sector can be characterized by the following features: a) sectoral nature (health care sector) b) specific budgetary directions (movement of funds from the state to local budgets) c) widespread use (used both in states with medical insurance and in states where the health sector is entirely publicly funded). The introduction of health insurance will change the purpose of the medical subvention. It will begin to play an important social function - to provide medical guarantees for vulnerable groups of the population.

\section{REFERENCES}

1. Subventions Allocation Information. Social Welfare Department. The Government of the Hong Kong Special Administrative Region. 2019. Available from: https://www.swd.gov.hk/en/index/site_ngo/ page_subventions/sub_modesofsub/id_subvention/[reviewed 2019.09.09].

2. The 2019 Long-Term Budget Outlook. Congressional Budget Office. Congress of the United States. 2019: 3. Available from: https:// www.cbo.gov/system/files/2019-06/55331-LTB0-2.pdf [reviewed 2019.09.07].

3. Ministry of Health Overview of Expenditure Estimates 2018-2019. Singapore. 2019:123. Available from: https://www.singaporebudget. gov.sg/docs/default-source/budget_2019/download/pdf/35MOH-2019.pdf [reviewed 2019.09.09].

4. Clarke D. Law, regulation and strategizing for health. In: Schmets G, Rajan D, Kadandale S, editors. Strategizing national health in the 21st century: a handbook. Geneva: World Health Organization; 2016: 14 Chapter 10. Available from: https://apps.who.int/iris/ bitstream/handle/10665/250221/ 9789241549745-chapter10 eng. pdf;jsessionid=3B3B2F53664COCE27BB8ED69AC29EFC5? sequence $=1$ [reviewed 2019.09.07].

5. Mossialos E, Djordjevic A, Osborn R, and others. International Profiles of Health Care Systems. The Commonwealth Fund, May 2017:181. Available from: https://www.commonwealthfund.org/sites/default/ files/documents/__media_files_publications_fund_report_2017_ may_mossialos_intl_profiles_v5.pdf [reviewed 2019.09.09].
6. Liu K, Yang J, Lu C. Is the medical financial assistance program an effective supplement to social health insurance for low-income households in China? A cross-sectional study. International Journal for Equity in Health. 2017:138. Available from: https://equityhealthj.biomedcentral.com/ articles/ 10.1186/s12939-017-0638-3 [reviewed 2019.09.10].

7. McIntyre D. Learning from experience: health care financing in low- and middle-income countries. Global Forum for Health Research. 2007: 41. Available from: http://announcementsfiles.cohred.org/gfhr_pub/ assoc/s14821e/ s14821e.pdf [reviewed 2019.09.08].

8. Hawkesworth I, Emery R, Wehner J, and others. Budgetung in Bulgaria. OECD Journal on Budgeting. 2009;3:142. Available from: http://www. oecd.org/governance/budgeting/46051594.pdf [reviewed 2019.09.07].

9. History of Health and Social Transfers. Department of Finance Canada. 2014. Available from: https://www.fin.gc.ca/fedprov/his-eng.asp [reviewed 2019.09.08].

10. Vilcu I, Mathauer I. State budget transfers to Health Insurance Funds for universal health coverage: institutional design patterns and challenges of covering those outside the formal sector in Eastern European high-income countries. Int J Equity Health. 2016; 15:7. doi: 10.1186/ s12939-016-0295-y.

11. Wildasin D. Intergovernmental Transfers to Local Governments. Municipal revenues and land policies. 2010:47-48. Available from: https://www.lincolninst.edu/sites/default/files/pubfiles/2059_1382_ LP2009-ch03-Intergovernmental-Transfers-to-Local-Governments_0. pdf [reviewed 2019.09.10].

12. Rajan D, Barroy H, Stenberg K. Budgeting for health. Chapter 8. Strategizing national health in the 21st century: a handbook. Geneva: World Health Organization; 2016: 14. Available from: https://apps.who. int/iris/bitstream/handle/10665/250221/9789241549745-chapter8eng.pdf?sequence $=11$ [reviewed 2019.09.05] (Ua).

13. Koncepciya reformi finansuvannya sistemi ohoroni zdorov'ya: rozporyadzhennya Kabinetu Ministriv Ukrayini vid 30 listopada 2016 r. № 1013-r [The concept of reforming the financing of the health care system: Resolution of the Cabinet of Ministers of Ukraine from 30.11.2016 № 1013-r]. Available from: https://zakon3.rada.gov.ua/ laws/show/1013-2016-p [reviewed 2019.09.12] (Ua).

14. Slovnikfinansovo-pravovih terminiv [Dictionary offinancial and legal terms]/ edited by Lidia K. Voronova. Second edition. Kyiv: Alerta, 2011. 467 p. (Ua).

15. Byudzhetnij kodeks Ukrayini: Kodeks Ukrayini, Zakon vid 08.07.2010 № 2456-VI v redakciyi vid 11.01.2019 r. [Budget Code of Ukraine: Codes of Ukraine]. Available from: https://zakon.rada.gov.ua/laws/show/245617 [reviewed 2019.09.12] (Ua).

16. Mizhbyudzhetni transferti (osvitnya ta medichna subvenciyi, bazova ta reversna dotaciyi) na 2019 rik [budget transfers (educational and medical subventions, base and reverse subsidies) for 2019]: Appendix No. 6 to the Law of Ukraine "On the State Budget of Ukraine for 2019" from 23.11.2018. Available from: https://zakon.rada.gov.ua/laws/ show/ 2629-19 [reviewed 2019.09.14] (Ua).

17. Mizhbyudzhetni transferti (osvitnya ta medichna subvenciyi, bazova ta reversna dotaciyi) na 2020 rik [budget transfers (educational and medical subventions, base and reverse subsidies) for 2020]: Appendix No. 5 to the Law of Ukraine "On the State Budget of Ukraine for 2020" from 14.11.2019. Available from: https://zakon.rada.gov.ua/laws/ show/ 2629-19 [reviewed 2020.08.15] (Ua).

18. Zvit Rahunkovoyi palati za 2017 rik [Report of the Accounts Chamber for 2017]. Kyiv: Accounts Chamber. 2018.316p. Available from: https:// rp.gov.ua/upload-files/Activity/Reports/Zvit_RP_2017.pdf[reviewed 2019.09.12] (Ua). 
19. Zvit Rahunkovoyi palati za 2018 rik [Report of the Accounts Chamber for 2018]. Kyiv: Accounts Chamber. 2019.156p. Available from: https:// rp.gov.ua/upload-files/Activity/Reports/2018/ZVIT_RP_2018.pdf [reviewed 2019.09.12] (Ua).

20. Zvit Rahunkovoyi palati za 2019 rik [Report of the Accounts Chamber for 2019]. Kyiv: Accounts Chamber. 2020.269p. Available from: https:// rp.gov.ua/upload-files/Activity/Reports/2019/ZVIT_RP_2019.pdf [reviewed 2019.09.12] (Ua).

21. Pro zatverdzhennya formuli rozpodilu obsyagu medichnoyi subvenciyi z derzhavnogo byudzhetu miscevim byudzhetam [Formula for the Distribution of Medical Subventions from the State Budget to Local Budgets]: Resolution of the Cabinet of Ministers of Ukraine from 08.19.2015 No. 618. Official Bulletin of Ukraine. 2015;69:113 (Ua).

22. Deyaki pitannya nadannya medichnoyi subvenciyi z derzhavnogo byudzhetu miscevim byudzhetam [Provision of Medical Subventions from the State Budget to Local Budgets]: Resolution of the Cabinet of Ministers of Ukraine from 23.01.2015 No. 11. Official Bulletin of Ukraine. 2015;7:70 (Ua)

\section{ORCID and contributionship:}

Oleksandr A. Lukashev: 0000-0002-3864-3728 A, D, E

Ihor Y. Krynytskyi: 0000-0002-8067-6769 A, D, E, F

Serhii V. Broiakov: 0000-0002-0636-7490 A, B, D,

\section{Conflict of interest}

The Authors declare no conflict of interest.

\section{CORRESPONDING AUTHOR \\ Serhii V. Broiakov \\ Pushkinskaya str., 77, 61024 Kharkiv, Ukraine \\ tel: +380506537751 \\ e-mail: sergbroyakov@icloud.com}

Received: 25.08 .2020

Accepted: 26.11 .2020

A - Work concept and design, B - Data collection and analysis, C - Responsibility for statistical analysis,

D-Writing the article, $\mathbf{E}$-Critical review, $\mathbf{F}$ - Final approval of the article 